This item was submitted to Loughborough's Research Repository by the author.

Items in Figshare are protected by copyright, with all rights reserved, unless otherwise indicated.

\title{
Coopetition and sales performance: Evidence from non-mainstream sporting clubs
}

PLEASE CITE THE PUBLISHED VERSION

https://doi.org/10.1108/IJEBR-05-2020-0273

PUBLISHER

Emerald

VERSION

AM (Accepted Manuscript)

\section{PUBLISHER STATEMENT}

This paper was accepted for publication in the journal International Journal of Entrepreneurial Behaviour and Research and the definitive published version is available at https://doi.org/10.1108/IJEBR-05-2020-0273.

\section{LICENCE}

CC BY-NC 4.0

\section{REPOSITORY RECORD}

Crick, Jim, and Dave Crick. 2020. "Coopetition and Sales Performance: Evidence from Non-mainstream Sporting Clubs”. Loughborough University. https://hdl.handle.net/2134/12931700.v1. 


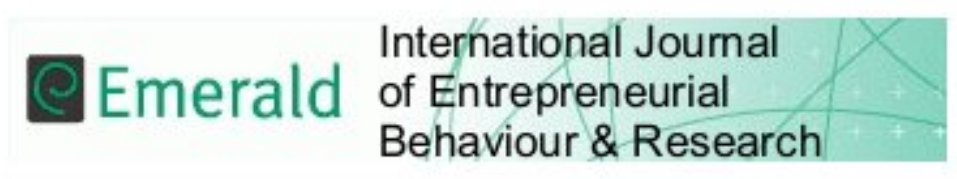

\section{COOPETITION AND SALES PERFORMANCE: EVIDENCE FROM NON-MAINSTREAM SPORTING CLUBS}

\begin{tabular}{|r|l|}
\hline Journal: & International Journal of Entrepreneurial Behavior \& Research \\
\hline Manuscript ID & IJEBR-05-2020-0273.R1 \\
\hline Manuscript Type: & Research Paper \\
\hline Keywords: & Entrepreneurs, Strategy \\
\hline \multicolumn{2}{|l}{}
\end{tabular}

\section{SCHOLARONE \\ Manuscripts}




\title{
COOPETITION AND SALES PERFORMANCE: EVIDENCE FROM NON-MAINSTREAM SPORTING CLUBS
}

\begin{abstract}
Purpose - Small sports clubs are the life-blood of particular communities, even though many are underresourced and have difficulties in operating under an individualistic business model. Although coopetition (simultaneous cooperation and competition) has been recognised as a positive driver of performance, the complexities of this association remain under-researched. Consequently, grounded in resource-based theory and the relational view, the purpose of this current study is to examine the moderating roles of inter-firm conflict and competitive intensity in the coopetition - sales performance relationship.
\end{abstract}

Design/methodology/approach - After undertaking 25 field interviews, survey data were collected from 151 non-mainstream sporting clubs in New Zealand. This setting was ideal, since it hosts high-degrees of cooperativeness and competitiveness. After assessing the statistical data for all major robustness checks (including common method variance and endogeneity bias), the hypothesised and control paths were tested through a hierarchical regression analysis.

Findings - Coopetition had a positive relationship with sales performance, but inter-firm conflict yielded a negative interaction effect. Surprisingly, this link was positively moderated by competitive intensity.

Practical implications - Under-resourced entrepreneurs (like those in many small sports clubs) should consider cooperating with their competitors, as these strategies can assist them to improve their sales performance. However, they should be careful when engaging in such activities due to the considerable risk that rival firms might behave opportunistically, which might harm their performance. That said, ownermanagers are advantaged if they operate in sectors where there are lots of competitors because there is increased scope to collaborate with "complementary" and trustworthy rivals that can help them to achieve mutually-beneficial outcomes. Indeed, sporting governing bodies (including those that operate on a non-profit basis) should encourage their members to engage in coopetition due to these positive financial consequences.

Originality/value - This investigation contributes to the extant literature by evaluating the competitive forces affecting the link between coopetition and sales performance. Specifically, new evidence emerges on the circumstances where coopetition is (and is not) a performance-enhancing entrepreneurial strategy. Further, this investigation provides unique insights regarding coopetition among non-mainstream sporting clubs, adding new knowledge to the sports entrepreneurship literature. Moreover, by infusing resource-based theory with the relational view, stronger arguments feature how owner-managers can navigate the paradoxical forces that drive coopetition activities. This study ends with several practitioner implications, alongside a series of limitations and avenues for future research.

Keywords: Coopetition, competitive intensity, inter-firm conflict, sales performance, resource-based theory, relational view, non-mainstream sports, sports entrepreneurship.

\section{Introduction}

"Although the sports market is hostile and competitive, it can be proposed that a collaborative strategy can enhance the business performance of the organisations involved" (Hammerschmidt et al., 2020, p. 2).

Recently, the global sports industry was valued at an estimated \$US 488.50 billion (The Business Research

Company, 2018). While a large proportion of this sum originates from mainstream sports in North America 
(World Trademark Review, 2017), non-mainstream sports are gaining popularity. For example, Liverpool Ladies Football Club has recently acquired large-scale sponsorship deals, Netball Australia has collaborated with major television channels to boost sales, and the rise in social media has improved access to online sports (including gambling on various events) in numerous countries (Adams, 2018). Although nonmainstream sports are becoming increasingly popular (Downward and Rasciute, 2010), many are underfunded (Ratten and Ratten, 2011). Despite non-mainstream sporting clubs often being the life-blood of certain communities, via job creation, health and well-being benefits, and crime prevention, they do not receive the same degree of public and private funding as mainstream sports ${ }^{1}$ (Ratten, 2010; Trussell, 2016). Consequently, some under-resourced (including non-mainstream) sporting organisations collaborate with their competitors (coopetition) to survive and grow within this rapidly changing industry (Vos and Scheerder, 2014; Crick and Crick, 2016a; Wemmer et al., 2016). This is opposed to employing an individualistic business model, whereby, owner-managers operate on the basis of their own resources and capabilities.

Coopetition is "a paradoxical relationship between two or more actors, regardless of whether they are involved in horizontal or vertical relationships, simultaneously in cooperative and competitive interactions" (Bengtsson and Kock, 2014, p. 180). Researchers have examined how sporting clubs might manage the interplay between cooperation and competition, including professional teams (Robert et al., 2009) and nonprofit sporting organisations (Lorgnier and Su, 2014). This is typically driven by under-resourced clubs collaborating with their competitors to access equipment and information (resources and capabilities, respectively) for mutually-beneficial performance consequences (Crick and Crick, 2016a). As noted throughout the entrepreneurship, marketing, and strategic management literature, while coopetition is likely to have a positive association with performance (Bengtsson and Kock, 2000; Ritala, 2012; Hannah and Eisenhardt, 2018; Kraus et al., 2019), limited research surrounds the nature of this association, in terms of

1 Taekwon-Do is not unified under the same rules and governing body and includes various break-away organisations with different spellings, like Taekwondo (see Crick and Crick, 2016; Moenig and Kim, 2017). Indeed, one form of the sport features in the Olympics, but this is separate to that featured in this current study. Moreover, it is not "mainstream", vis-à-vis, sports, such as football (as per Downward and Rasciute, 2010). Hence, the term "non-mainstream" is utilised. 
the moderating factors that might affect the coopetition paradox. In fact, firm-level and environmental-level competitive forces (like inter-firm conflict and competitive intensity) might distort the relationship between coopetition and performance (see Hoffmann et al., 2018; Crick, 2019; Czakon et al., 2020). Such contingencies may provide new insights into the circumstances where coopetition is (and is not) a performance-driving entrepreneurial strategy.

Consequently, under resource-based theory and the relational view (see Barney, 1991; Lavie, 2006; Dyer et al., 2018), the objective of this current study is to explore certain firm-level and environmental-level competitive forces affecting the relationship between coopetition and sales performance. By applying coopetition activities to a non-mainstream sporting context (with clubs allowed to make profits, but affiliated to a non-profit governing body), this investigation offers insights into how such organisations can survive and grow within their markets ${ }^{2}$. By addressing the research objective, three contributions are made to strengthen the entrepreneurship literature:

1. Unique insights evidence how firm-level and environmental-level competitive forces (inter-firm conflict and competitive intensity) can moderate the link between coopetition and sales performance (building upon Hoffmann et al., 2018; Czakon et al., 2020; Crick and Crick, 2021).

2. Resource-based theory and the relational view are integrated as theoretical perspectives that offer new knowledge into the nature of the relationship between coopetition and sales performance (following Dyer and Singh, 1998; Lavie, 2006; Dyer et al., 2018).

\footnotetext{
2 This study contributes to the cross-disciplinary literature by offering new and improved insights into the relationship between coopetition and sales performance (for example, building upon Ritala, 2012; Felzensztein et al., 2014; Hoffmann et al., 2018; Czakon et al., 2020). Nonetheless, the sports industry provides a unique setting for making this theoretical contribution (as noted by Robert et al., 2009; Lorgnier and Su, 2014; Crick and Crick, 2016). That is, context is vital in entrepreneurial research because it allows scholars to shape theory with novel evidence from a setting that develops academics' understanding of practical applications of theories (Jones and Rowley, 2011). Since sports entrepreneurship refers to the innovative, proactive, and risk-taking behaviours employed by sporting organisations (Ratten, 2012), this current investigation evaluates coopetition as an entrepreneurial strategy within a sporting context.
} 
3. Coopetition is examined within non-mainstream sporting clubs to illustrate an alternative perspective regarding how such organisations collaborate with their competitors (extending Robert et al., 2009; Lorgnier and Su, 2014; Wemmer et al., 2016; Hammerschmidt et al., 2020).

To make these three contributions, this paper is structured as follows. First, the conceptual framework is presented, alongside the research hypotheses and control paths. Second, the adopted methodology is described. Third, the empirical results are presented. Fourth, these results are discussed in relation to the extant literature. Fifth, the study is concluded, with several practitioner implications and a series of limitations and avenues for future research.

\section{Theory and hypotheses}

\section{Overview of resource-based theory}

The resource-based view examines the link between organisational resources and capabilities and company performance (Barney, 1991; 2001). A seminal component of this theoretical lens is the value, rarity, inimitability, and non-substitutability (VRIN) framework, which focuses on the extent to which firms' tangible and intangible assets yield higher-levels of performance (Barney, 1991). Nevertheless, company performance can be measured in various capacities, including sustainable competitive advantages and other financial metrics (Ray et al., 2004; Crick and Crick, 2021). In this current study, sales performance was utilised as the outcome variable because it assesses the degree to which owner-managers have created value for their target markets by acquiring revenues from their customers (following Morgan et al., 2009). Likewise, sporting clubs have been found to utilise sales performance as an appropriate measure, since they require this income to operate (see Lorgnier and Su, 2014; Wemmer et al., 2016). In turn, sales performance was conceptualised as a key outcome of coopetition strategies. In doing so, the seminal foundations of the resource-based view were considered (like the VRIN framework), alongside more recent developments that have been made to this theoretical lens (building upon Hannah and Eisenhardt, 2018; Crick et al., 2020). 
Extensions to the resource-based view

The core elements of resource-based theory pertained to how decision-makers can leverage their tangible and intangible assets to achieve higher-levels of performance (see Barney, 1991). However, this viewpoint has evolved, in terms of its assumptions relating to how companies can operate within their markets (Barney et al., 2001; Nason and Wiklund, 2018). As one of the most famous illustrations, Barney (2001) and Priem and Butler (2001) debated over the strengths and weakness of the resource-based view, finding that it needed to account for the volatility of the competitive business environment - and its impact on the performance outcomes of firm-level resources and capabilities. Under this logic, this current investigation draws upon this body of knowledge suggesting that while coopetition might serve as a performanceenhancing entrepreneurial strategy (Ritala, 2012; Hannah and Eisenhardt, 2018), this link could be unhinged by certain environmental-level factors, like competitive intensity (Hoffmann et al., 2018; Crick and Crick, 2021). These conceptual arguments were intended to unpack the relationship between coopetition and sales performance by appreciating the complexities that could impact this association (extending Crick, 2019; Czakon et al., 2020). As another point, the debate between Barney (2001) and Priem and Butler (2001) stressed that authors should distinguish between resources and capabilities, as entrepreneurs utilise their tangible and intangible assets in different respects in the day-to-day and long-term operations. This current study noted this theoretical development in its employment of the resource-based view to examine the dynamics of behavioural forms of coopetition (as per Dana and Winstone, 2008; Bouncken and Kraus, 2013; reference withheld; Felzensztein et al., 2019).

\section{Integrating resource-based theory and the relational view}

Although the resource-based view can help explain how sharing resources and capabilities with certain competitors can positively impact company performance (Ritala, 2012; Hannah and Eisenhardt, 2018), it does not sufficiently consider the relational factors that underpin these entrepreneurial strategies (as noted by Crick and Crick, 2020). In fact, recently, Barney (2018) recommended that resource-based theory should 
encapsulate a stakeholder perspective to show how organisations must foster effective networks (like with customers, supply chain partners, and competitors) to survive and grow within their markets. This is inkeeping with the themes of coopetition, whereby, decision-makers need to have strong connections with their competitors to not only yield higher-levels of performance, but also, to avoid certain tensions (such as conflict, power imbalances, and opportunistic behaviours) that might emerge if these partnerships are poorlymanaged (following Tidstrom, 2009; Bouncken et al., 2018).

Accordingly, certain research has infused resource-based theory with the relational view to explore the cooperative and competitive facets of the coopetition construct (see Lavie, 2006; Crick and Crick, 2020). That is, the relational view highlights that a pertinent driver of company performance is having high-quality relationships with a range of stakeholders, not least of which competitors (Dyer and Singh, 1998; Dyer et al., 2018). For instance, Crick and Crick (2020) infused these theoretical lens to demonstrate how several businesses (throughout the world) have been cooperating with their competitors to cope with the health and economic-related shocks associated with the COVID-19 pandemic. They noted that on its own, the resourcebased view tells an incomplete story regarding coopetition activities, which is enhanced by drawing upon the relational view. Consequently, this current investigation follows this approach to unpack the complexities of the coopetition - sales performance link. This includes how inter-firm conflict could be an underlying mechanism that could distort this relationship (see Ritala and Hurmelinna-Laukkanen, 2013; Raza-Ullah et al., 2014). These theoretical viewpoints shed light on why it is important that owner-managers should collaborate with "complementary" rivals, in terms of those that they can trust to achieve mutually-beneficial outcomes (Czakon et al., 2020; Crick and Crick, 2021).

\section{Sports entrepreneurship and coopetition}

There have been various conceptualisations and operationalisations of the coopetition construct (see Bengtsson and Kock, 2014; Hoffmann et al., 2018). That said, a seemingly agreed point is that coopetition is the interplay between cooperation and competition, whereby, decision-makers share resources and 
capabilities with their competitors for mutually-beneficial outcomes, not least of which higher-levels of sales performance (Ritala, 2012; Hannah and Eisenhardt, 2018; reference withheld). As noted earlier, this current study contributes to the wider entrepreneurship literature by infusing resource-based theory and the relational view (as per Lavie, 2006; Crick and Crick, 2020) to evaluate the relationship between coopetition and sales performance under the moderating roles of inter-firm conflict and competitive intensity. This theoretical contribution is tested in the capacity of non-mainstream sporting organisations in New Zealand to contextualise the extent to which these firm-level and environmental-level competitive forces might impact this association. Sports entrepreneurship is a domain that has been applied to various settings and strategies around the globe (see Ratten and Ratten, 2011; Vos and Scheerder, 2014; Ratten, 2016). More importantly, the broader sports industry has been found to be active in coopetition activities (Robert et al., 2009; Lorgnier and Su, 2014; Crick and Crick, 2016a; Hammerschmidt et al., 2020). Henceforth, by drawing upon this body of knowledge, the sports entrepreneurship field was effective for examining these under-researched issues involving coopetition. Yet, for clarity, it is argued that the non-mainstream context was used to develop rich insights into the complexities of the coopetition paradox, for which broader implications are made towards entrepreneurs operating in more mainstream settings - inside and outside of sport.

\section{Conceptual framework}

Grounded in resource-based theory and the relational view (Lavie, 2006; Crick and Crick, 2020), the study's conceptual framework (Figure 1) contained three research hypotheses and two main control paths. As mentioned earlier, sales performance was chosen as the outcome variable, as many organisations (including those associated with sport) must yield sales revenues from their customers/club members to achieve their objectives (Lorgnier and Su, 2014; Wemmer et al., 2016). First, it was expected that coopetition has a positive relationship with sales performance (Ritala, 2012; Felzensztein et al., 2014; Hannah and Eisenhardt, 2018; Estrada and Dong, 2020). Second, the link between coopetition and sales performance was anticipated to be negatively moderated by inter-firm conflict (Raza-Ullah et al., 2014; Bouncken et al., 2018; Hoffmann et 
al., 2018). Third, it was proposed that competitive intensity negatively moderates the coopetition - sales performance relationship (Tidstrom, 2009; Crick, 2019). Fourth, the outcome variable (sales performance) was controlled for firm size and firm age, as additional factors that might explain its variance (Westhead et al., 2001; Jaskiewicz et al., 2015; Nason and Wiklund, 2018). Fourth, to test these interaction effects, several procedural controls were included within the model (Boso et al., 2013; Crick and Crick, 2021).

[Insert Figure 1 about here]

\section{Coopetition and sales performance}

Coopetition strategies are comprised of cooperative and competitive behaviours (Bengtsson and Kock, 2000; Bengtsson and Johansson, 2014; Raza-Ullah et al., 2014; Granata et al., 2018). This means that organisations must carefully manage the paradoxical forces of cooperativeness and competitiveness to yield higher-levels of sales performance (Czakon et al., 2020). By collaborating with their rivals, decision-makers can understand issues surrounding their competitive business environments by learning about the wants and needs of customers (Thomas et al., 2013; Bouncken et al., 2018; Kraus et al., 2019). Furthermore, coopetition allows owner-managers to access assets, such as equipment and knowledge needed to effectively operate their businesses, but that could be very costly to purchase, or to help fund joint promotions among partners (Dana and Winstone, 2008; Felzensztein et al., 2014; Wemmer et al., 2016; Estrada and Dong, 2020). For example, this might involve borrowing equipment needed periodically from a competitor, rather than buying it themselves (Dana et al., 2013). In doing so, firms can increase their sales, foster unique selling points, and conserve costs (Bernal et al., 2002; Hoffmann et al., 2018). As an illustration, Felzensztein et al. (2018) found that in regional clusters, entrepreneurs could use coopetition to create superior value for their customers, develop efficient supply chains, and save money by running joint promotions.

Likewise, Felzensztein et al. (2010) explored the driving forces behind inter-firm cooperation (a very similar notion to coopetition) in the context of the Scottish and Chilean salmon fishing sectors. They developed a conceptual model that signifies that geographic proximity manifests into informal social networks (also driven 
by the regional culture/environment), which in turn, leads to entrepreneurs engaging in certain forms of interfirm cooperation ${ }^{3}$. Thus, it stands to reason that if entrepreneurs have access to effective social capital, they can collaborate with "complementary" rivals that assist them to yield higher-levels of sales performance. Collectively, these are advantages that span from working with industry rivals that would not exist under individualistic business models (Bengtsson and Johansson, 2014; Kraus et al., 2019). Consequently, consistent with resource-based theory and the relational view, coopetition can provide organisations with new resources, capabilities, and opportunities (including social capital) that might yield higher-levels of sales performance (Bengtsson and Kock, 2014; Hannah and Eisenhardt, 2018; Felzensztein et al., 2019). For clarity, these new tangible and intangible assets can overcome the drawbacks of an individualistic business model, with a likely consequence being increased sales performance (Ritala, 2012; reference withheld). This logic is underpinned by the key assumption that firms cooperate with "complementary" rivals (Czakon et al., 2020). Hence, it is expected that:

H1. A positive relationship exists between coopetition and sales performance.

\section{The moderating role of inter-firm conflict}

Under the relational view (and the stakeholder lens associated with resource-based theory), the quality of the relationships between the rivals engaging in coopetition is highly important (Lavie, 2006; Barney, 2018; Dyer et al., 2018). If trust does not exist, there is unlikely to be a great deal of resource and capability-sharing activities (Tidstrom, 2009; Kraus et al., 2019). Specifically, if there are tensions involved in coopetition strategies, entrepreneurs might feel uncomfortable sharing their assets with their competitors due to potential risks, like losing intellectual property (Ritala and Hurmelinna-Laukkanen, 2013). With inter-firm conflict (the extent to which businesses experience tensions with their industry rivals), there could be a lack of efficiency

\footnotetext{
3 The notion of social capital's prevalence among firms within close geographic proximity is observed across various sectors like restaurants (Chaudhry and Crick, 2004), accommodation (Crick and Crick, 2016b), and agriculture/fisheries (Felzensztein et al., 2010).
} 
in implementing coopetition strategies, as time and effort could be invested into resolving such conflict, when it would be more effective to focus on performance-driving activities (Bouncken and Kraus, 2013; Bouncken et al., 2018). Owing to the inter-firm trust-based themes of the relational view (Dyer and Singh, 1998; Dyer et al., 2018), if inter-firm conflict exists, the lack of trust between these competitors might unbalance the coopetition paradox (Raza-Ullah et al., 2014). This is because decision-makers might struggle to differentiate the paradoxical forces of cooperativeness and competitiveness and lose sales through working with untrustworthy and opportunistic industry rivals (Czakon et al., 2020). For example, Crick et al. (2020) indicated that if entrepreneurs in the New Zealand wine sector cooperate with rivals that they have tensions with, they could experience harmful performance outcomes (including reduced sales) because they have shared valuable resources and capabilities with untrustworthy rivals. Therefore, inter-firm conflict could create confusion about whether coopetition is a performance-driving entrepreneurial strategy (Ritala and Hurmelinna-Laukkanen, 2013; Hoffmann et al., 2018). Put another way, inter-firm conflict is a firm-level competitive force pertaining to entrepreneurs cooperating with tension-prone businesses that can reduce the performance outcomes of these activities (extending Tidstrom, 2009; reference withheld). Consequently, it follows that:

H2. Inter-firm conflict negatively moderates the relationship between coopetition and sales performance.

\section{The moderating role of competitive intensity}

As already mentioned, key market-level conditions have been incorporated into resource-based theory (with applications under the relational view) to evaluate the performance outcomes of organisational resources and capabilities (Barney, 2001; Priem and Butler, 2001; Crick and Crick, 2021). The competitive business environment is an important element of the coopetition literature, as it emphasises how rivalrous behaviours can potentially affect the coopetition paradox (Ritala, 2012; Bengtsson and Johansson, 2014). Following the themes of resource-based theory and the relational view, the competitive business environment can 
moderate the coopetition - sales performance relationship in two capacities (reference withheld). One schoolof-thought is that as more competitors enter a market, decision-makers can be selective of which rivals that they can share resources and capabilities with and not least within business clusters (Felzensztein and Deans, 2013; Felzensztein et al., 2018; Granata et al., 2018). This is consistent with Felzensztein et al.'s (2010) study regarding how inter-firm cooperation (again, a very similar activity to coopetition) is driven by companies being able to acquire their rivals' tangible and intangible assets. Another school-of-thought is that as markets become more competitive, owner-managers might struggle to differentiate the paradoxical forces of cooperativeness and competitiveness (Tidstrom, 2009).

Indeed, if there is a high-degree of competitive intensity, this environmental-level force could create more tensions between industry rivals (like conflict, power imbalances, and opportunistic behaviours), which makes it difficult for decision-makers to know which rivals they can trust (Bouncken and Kraus, 2013; Bouncken et al., 2018). Additionally, higher-levels of competitive intensity might yield other negative outcomes, like stolen intellectual property and diluted competitive advantages between coopetition partners (Ritala and Hurmelinna-Laukkanen, 2013). This is because the competitive business environment could de-stabilise the delicate nature of the interplay between cooperation and competition (Hoffmann et al., 2018; Crick and Crick, 2021). In fact, Bouncken et al. (2018) noted that if entrepreneurs work with poorly-chosen industry rivals (those that could behave opportunistically for their own gains) in coopetition partnerships, they could lose valuable resources and capabilities, be less innovative, and not be as competent at producing new goods and services. This suggests that higher-degrees of rivalry (through competitive intensity as a market-level force) could prevent entrepreneurs from utilising coopetition strategies to improve their sales performance if not effectively managed (Crick, 2019). For these reasons, it anticipated that:

H3. Competitive intensity negatively moderates the relationship between coopetition and sales performance. 


\section{Control paths}

The outcome variable (sales performance) was controlled for firm size and firm age. Specifically, larger organisations, with a greater volume of resources and capabilities, have a stronger chance of out-performing smaller rivals within their markets (Barney, 1991). Thus, firm size was used as a control variable. Additionally, there are other ways that businesses can improve their performance other than through their size (Dyer and Singh, 1998; Kellermanns et al., 2016; Nason and Wiklund, 2018). For instance, older firms can utilise their market experience and heritage, such as via their networks, to enhance sales performance compared to newer competitors (Westhead et al., 2001; Jaskiewicz et al., 2015). Consequently, firm age featured as a control path. The adopted methodology follows in the next section.

\section{Methodology \\ Empirical context}

An ideal empirical context for studying coopetition is one that is highly-cooperative and highly-competitive (Bengtsson and Kock, 2014; Granata et al., 2018). Likewise, coopetition-based research is best-conducted in a setting where firms can access key resources and capabilities from their rivals, including being located within a close geographic proximity (Felzensztein and Deans, 2013; reference withheld; Felzensztein et al., 2018). As certain sporting organisations are often active in coopetition strategies, not least of which being able share tangible and intangible assets with their rivals (Robert et al., 2009; Lorgnier and Su, 2014), the research team worked with an International Taekwon-Do Federation (ITF) governing body in New Zealand, with over 3,500 members and 262 instructors (the sampling frame). Following Felzensztein et al.'s (2010) arguments, certain forms of coopetition are more likely to be implemented in sectors that exhibit social connections and informal relationships. These dynamics were anticipated to be prominent within a New Zealand sporting context (see Crick and Crick, 2016a), influencing the research team's decision to utilise this population of interest. Taekwon-Do is a martial art that was established in 1955 by the late General Choi Hong Hi (IX Degree Black Belt) to teach hand-to-hand combat to soldiers in the South Korean military (Ahn 
et al., 2009). However, since its formation, Taekwon-Do divided into various break-away organisations due to the ongoing political volatility between North Korea and South Korea (see Moenig and Kim, 2017). As previously alluded to, since the sport exhibits different rules among organisations with no single (unified) governing body and does not have the same following as "mainstream" sports, like football (as per Downward and Rasciute, 2010), it is termed "non-mainstream" in this current study. This is despite one style of TaekwonDo featuring in the Olympics, but not the form of the sport studied in this current investigation (see Crick and Crick, 2016a). Nevertheless, consistent with earlier sports research, clubs are competitive due to the political climate affecting sport, as well as the sheer volume of substitute and "complementary" rivals within the sector (see Ratten, 2019).

\section{Generalisability}

The cooperative and competitive dynamics of the empirical context allowed the research team to explore the complexities of the coopetition - sales performance relationship (following Bengtsson and Kock, 2014; Felzensztein et al., 2018). Additionally, the use of empirical data from non-mainstream sporting clubs (affiliated to a non-profit governing body) illustrated an alternative setting where firms collaborate with their competitors (building upon Lorgnier and Su, 2014). As noted by Wemmer et al. (2016), the non-profit sector in sport is multi-faceted, for which there can be overlaps between organisations that have for-profit, vis-à-vis, non-profit business models. They argued that certain organisations have the authority to turn profits, but are required to follow certain protocols set by a non-profit governing body. Such processes were present during this current study, whereby for clarity, the individual Taekwon-Do clubs were profit-making businesses; however, the overall governing body was non-profit-oriented. In addition, earlier work has sampled sporting clubs to evaluate theoretical issues and make inferences towards mainstream organisations (as noted by Ratten, 2016). Consequently, by examining the coopetition - sales performance link under the moderating roles of inter-firm conflict and competitive intensity in the sporting context, this study has potential wider generalisability. 


\section{Key informants}

Scholars have predominately sampled owner-managers to investigate coopetition (Tidstrom, 2009; RazaUllah et al., 2014; Hoffmann et al., 2018). Owner-managers are normally the individuals that decide to collaborate with their competitors, since they have the authority to share critical resources and capabilities (Bengtsson and Kock, 2000; Felzensztein and Deans, 2013; Hannah and Eisenhardt, 2018). Taekwon-Do instructors are the most senior officials in their clubs and are typically the owners (Ahn et al., 2009; Crick and Crick, 2016a; Moenig and Kim, 2017). This meant that Taekwon-Do instructors had the expertise to answer the questions about all constructs within the conceptual framework, not least of which sales performance. As such, these individuals featured as the key informants. As mentioned later, an informant quality scale (adapted from Boso et al., 2013) was used to evaluate the knowledge of the participants, revealing they were well-suited to the themes of this current investigation.

\section{Field interviews}

To shape the operationalisations in the survey, 25 semi-structured interviews were conducted with senior members of the governing body and club instructors (as per Katsikeas et al., 2006). Specifically, these field interviews were used to adapt the established measurement scales (as outlined later, that typically featured sectors other than sports) to the chosen sporting context, so that the key informants could answer "relevant" questions. For instance, the field interviews explored whether sales performance is an acceptable measure of success among sporting clubs, for which no problems were identified (reinforcing Lorgnier and Su, 2014; Wemmer et al., 2016). Indeed, the importance of sales revenue from the volume of students (in effect, customers in a commercial business sense) featured in the field interviews to demonstrate the need to reinvest money into the club over and above covering operating costs, like hiring the use of facilities for training. Moreover, another illustration involved the ways that coopetition is implemented, such as sharing equipment among clubs, senior instructors providing guest seminars, information sharing for less experienced instructors, etc. These interviews lasted approximately sixty minutes. The research team analysed this 
qualitative data using the constant comparison technique, whereby, re-occurring themes were utilised to identify a point of theoretical saturation (Suddaby, 2006). Moreover, manual coding allowed the researchers to get "close" to the data; hence, concentrate on the most relevant arguments (see Miles and Huberman, 1994).

\section{Electronic survey}

The substantive research method used within this investigation was an electronic survey (through Qualtrics). Once the survey was designed, it was pre-tested with a sample of knowledgeable academics $(n=10)$ and practitioners $(n=20)$ who could comment on the constructs that were being measured (Dana and Dana, 2005). The pre-testing stage did not reveal any concerns. Then, a pilot study was undertaken $(n=31)$, whereby, the data were assessed for their descriptive statistics and scale reliabilities (Birley and Westhead, 1994). Since the data were of a high-quality, no changes were made to the survey. Next, the core study was launched $(n=120)$. As the measures that appeared in the pilot study were identical to those in the core study, the two datasets were merged to yield the final sample (Crick et al., 2020). The 151 observations (from a population of 262 instructors) accounted for an acceptable response rate (57.63\%) to test the model under investigation. This was attributed to the survey being relatively short and interactive (Newby et al., 2003). The data were checked for early, vis-à-vis, late response bias by conducting $t$-tests for each construct (Boso et al., 2013), revealing non-significant differences.

\section{Operationalisations}

The constructs within the conceptual framework were measured as follows ${ }^{4}$ (Appendix 1 displays a full-list of the multi-item measurement scales). First, coopetition was operationalised using a seven-point Likert scale, with three items, ranging from: 1 = very strongly disagree to 7 = very strongly agree (adapted from Bouncken

\footnotetext{
4 The following construct abbreviations were used - coopetition (COOP), sales performance (SALES), competitive intensity (COMP), inter-firm conflict (CONF), firm size (SIZE), firm age (AGE), coopetitionoriented mind-set (COM), and informant quality (INQ).
} 
and Kraus, 2013; Bouncken et al., 2018). The coopetition construct has been measured in various ways, such as using weak proxies or single-indicators (see Ritala, 2012; Felzensztein et al., 2014; Estrada and Dong, 2020). The adopted scale was chosen, since it captures the propensity of coopetition activities via the extent to which organisations cooperate with their competitors. Second, sales performance was operationalised on a nine-point interval scale, with three items, ranging from: $1=$ extremely dissatisfied to 9 = extremely satisfied (adapted from Morgan et al., 2009). Third, competitive intensity was measured on a seven-point Likert scale, with three items, ranging from: 1 = very strongly disagree to 7 = very strongly agree (adapted from Slater et al., 2006). Fourth, inter-firm conflict was captured on a seven-point Likert scale, with five items, ranging from: 1 = very strongly disagree to 7 = very strongly agree (adapted from Xie et al., 1998). Fifth, firm size was measured via the total number of Taekwon-Do instructors/students (adapted from Crick and Crick, 2016a). Sixth, firm age was captured by the number of years that the sporting clubs (as "businesses") had been operating (following Westhead et al., 2001). Seventh, to test for endogeneity bias (as discussed later), the instrumental variable was a coopetition-oriented mind-set, which was measured using a seven-point Likert scale, with six items, ranging from: $1=$ very strongly disagree to $7=$ very strongly agree (adapted from Crick and Crick, 2019; reference withheld). Eighth, the survey ended with an informant quality measure, which involved a seven-point Likert scale, with five items, ranging from: 1 = very strongly disagree to 7 = very strongly agree (adapted from Boso et al., 2013).

\section{Data analysis}

The following data analysis techniques were employed in this study. First, using SPSS 23, the descriptive statistics of the initial measures were analysed, with a focus on their variances (Chandler and Lyon, 2001). This showed that a good mixture of sports clubs had participated in this study (Table 1). As mentioned earlier, all the Taekwon-Do clubs were permitted to turn profits, but were affiliated to a non-profit governing body. Yet, for clarity, the sampled organisations were private enterprises.

[Insert Table 1 about here] 
Second, turning to Table 2, through SPSS 23, an exploratory factor analysis was conducted, with a principal components analysis extraction and a varimax rotation (Poutziouris, 2003). The Kaiser-Meyer-Olkin (KMO) test of sampling adequacy was employed (0.78), alongside Bartlett's test of sphericity $\left(X^{2}=4,141.72 ; d f=\right.$ 325 ; Sig. $=0.00)$, while explaining a relatively high-degree of variance $(79.08 \%)$.

\section{[Insert Table 2 about here]}

Third, as shown in Table 3, using LISREL 9.30, a confirmatory factor analysis was "run" to delete items if they had low standardised factor loadings, high standardised error variances, non-significant $t$-values, and issues associated with the modification indices (Adomako et al., 2016). Furthermore, after the scale purification stage, the model fit indices were within the minimum benchmarks $\left(X^{2}=195.13 ; d f=126\right.$; Sig. $=$ $\left.0.00 ; X^{2} / d f=1.55 ; \mathrm{RMSEA}=0.06 ; \mathrm{CFI}=0.97 ; \mathrm{IFI}=0.97 ; \mathrm{NNFI}=0.96 ; \mathrm{GFI}=0.89 ; \mathrm{SRMR}=0.04\right)$.

\section{[Insert Table 3 about here]}

Fourth, after analysing the bivariate correlations and descriptive statistics of the latent variables (via SPSS 23), the hypothesised and control paths were tested through a six-step hierarchical regression analysis (Morgan et al., 2009). The research team used "residual-centering" to transform the interaction effects to reduce multi-collinearity errors (Tiwana, 2008). The research hypotheses and control paths were evaluated during the final stage of the analysis, since all independent variables were "nested" within the model (following Wiklund and Shepherd, 2005; Covin et al., 2006). Furthermore, the model fit summaries were recorded, alongside the change statistics - to supplement the unstandardised regression coefficients $(\beta)$, the $t$-values, and their significances (as per Crick et al., 2020).

\section{Reliability and validity}

Reliability was assessed through the Cronbach's alpha coefficients (a) for the multi-item scales before and after they were purified - all exhibiting values above 0.70 (Knight, 1997; Dai et al., 2014). Face validity was checked through pre-testing the survey with a sample of knowledgeable academics $(n=10)$ and practitioners 
$(n=20)$, who indicated that it was understandable and covered appropriate theoretical and practical issues (Dana and Dana, 2005). Content validity was assured via employing established operationalisations (Marvel and Lumpkin, 2007), as well as conducting the 25 field interviews to ensure that the measurement scales were correctly adapted to the population of interest (Katsikeas et al., 2006). Convergent validity was evaluated through the final scales having composite reliabilities (CRs) that were greater than 0.60 and average variance extracted values (AVEs) exceeding 0.50 (Schillo et al., 2016). Discriminant validity was tested by examining the squared phi matrix correlations (accessed from LISREL 9.30) and comparing them against the AVEs for each construct. As the highest squared phi matrix correlation (0.26) was less than the lowest AVE (0.69), discriminant validity is likely to exist (Morgan et al., 2015). Table 4 displays the final multiitem scale reliabilities.

\section{[Insert Table 4 about here]}

\section{Common method variance}

Common method variance was evaluated through designing the survey in a way that made it as short and interactive as possible for the respondents to minimise their fatigue (Podsakoff et al., 2003). Once the final measures had been established, the marker variable technique was utilised via SPSS 23 as follows (see McGee and Peterson, 2019). First, a bivariate correlation matrix was produced, containing all the constructs within the conceptual framework. Second, a partial correlation matrix was created, containing the same latent variables, but controlling for the informant quality scale (the marker variable - adapted from Boso et al., 2013). Third, the differences between the bivariate and partial correlation matrices were averaged. As the mean correlation was very small $(r=0.00)$, the data were unlikely to be biased by a common method factor (Lindell and Whitney, 2001).

\section{Endogeneity bias}

To test for endogeneity bias, the research team undertook the following procedures. First, the conceptual framework was refined to test the coopetition - sales performance relationship (controlling for firm size and 
firm age). Second, a variable that was conceptually associated with coopetition, but not sales performance was selected - a coopetition-oriented mind-set (Estrada and Dong, 2020). Third, via LISREL 9.30, two structural models were "run" - one assuming endogeneity did not exist and another where the instrumental variable was added (Crick et al., 2020). Fourth, as the $\Delta x^{2}$ (15.40), relative to the $\Delta d f(12)$, was non-significant (less than the critical value of 21.03), the statistical data were deemed to be unaffected by endogeneity bias (Semadeni et al., 2014). The study's results follow in the next section.

\section{Results}

The bivariate correlations (and their descriptive statistics) revealed the underlying relationships within the statistical data (Table 5). During the hierarchical regression analysis, coopetition had a positive and significant relationship with sales performance $(\beta=0.48 ; t=5.20)$, supporting $\mathrm{H} 1$. Turning to the moderators, inter-firm conflict negatively moderated the coopetition - sales performance link $(\beta=-0.08 ; t=-2.14)$, supporting H2. Surprisingly, competitive intensity yielded a positive interaction effect in the relationship between coopetition and sales performance $(\beta=0.11 ; t=2.30)$, offering a counter-intuitive viewpoint to $\mathrm{H} 3$. Moreover, mixed support existed for the two main control paths. Specifically, there was a positive and significant link for firm age $(\beta=0.23 ; t=3.28)$, but a positive and non-significant association for firm size $(\beta$ $=0.14 ; t=0.78$ ). Additionally, as shown in Table 6 , in the final (nested) stage of the hierarchical regression analysis, following the adjusted $R^{2}$, a relatively high amount of variance was explained (23\%), alongside significant change statistics $\left(\Delta R^{2}=0.03 ; \Delta F=5.28\right)$. These results are discussed in the next section.

[Insert Tables 5 and 6 about here]

\section{Discussion}

Prior research has found that by collaborating with competitors, under-resourced entrepreneurs can learn how to better-understand their competitive business environments, as well as experiencing the advantages from acquiring new resources, capabilities, and opportunities that would not exist under individualistic business models (Bouncken and Kraus, 2013; Hannah and Eisenhardt, 2018; Kraus et al., 2019). Indeed, 
such conceptualisations have infused into the sports industry, whereby, sporting organisations (clubs) sometimes share resources and capabilities with industry rivals to obtain mutually-beneficial outcomes, including improved sales performance (Robert et al., 2009; Lorgnier and Su, 2014; Hammerschmidt et al., 2020). There have been recent calls for research to investigate the complexities of this association (Hoffmann et al., 2018; Czakon et al., 2020). More specifically, an under-researched area surrounds the coopetition paradox to evaluate how certain firm-level and environmental-level competitive forces could de-stabilise the delicate nature of the interplay between cooperation and competition (Bouncken et al., 2018; Crick, 2019). As such, guided by resource-based theory and the relational view (Barney, 1991; Lavie, 2006; Dyer et al., 2018), this current investigation sought to examine how inter-firm conflict and competitive intensity could negatively moderate the relationship between coopetition and sales performance in non-mainstream sports clubs. This context was important, since a large proportion of clubs are under-funded (Ratten and Ratten, 2011), despite being the life-blood of many communities (Ratten, 2010; Trussell, 2016). Thus, it offered rich contextual insights to supplement this theoretical contribution.

The results indicated that coopetition has a positive link with sales performance - supporting a variety of studies that have explored the performance-driving benefits of behavioural forms of coopetition (see Ritala, 2012; reference withheld; Felzensztein et al., 2018; Estrada and Dong, 2020). Inter-firm conflict was found to negatively moderate this link (Figure 2), which could be attributed to the tense relations between competing businesses making it difficult for decision-makers to know which rivals that they can trust and share resources and capabilities with (Raza-Ullah et al., 2014; Czakon et al., 2020). Earlier studies have suggested that if coopetition occurs between competitors that are untrustworthy, there can be conflict, power imbalances, and opportunistic behaviours that damage the quality of these coopetition-based partnerships (Tidstrom, 2009; Bouncken and Kraus, 2013). Inter-firm conflict, coupled with coopetition, can lead to firms losing intellectual property and diluting their competitive advantages (Ritala and Hurmelinna-Laukkanen, 2013; Crick et al., 2020). Within under-resourced sports clubs, the field interviews provided an illustration, whereby, conflict might arise from losing members to rival clubs, leading to decreased sales. For example, following certain 
forms of collaboration, members may choose to attend training sessions with an instructor in a rival club with whom have they developed an affinity. In short, new evidence has emerged on a firm-level competitive force that can distort the coopetition paradox (responding to Hoffmann et al., 2018; Crick, 2019). As such, coopetition can enhance firms' resources and capabilities - consistent with the stakeholder perspective of the resource-based view (Barney, 2018). However, linking with the relational view (Dyer and Singh, 1998; Dyer et al., 2018), there can be harmful effects on sales performance if companies collaborate with industry rivals where there are conflict-based tensions (Tidstrom, 2009; Bouncken et al., 2018; Crick and Crick, 2021).

\section{[Insert Figure 2 about here]}

Another interesting contribution was that instead of negatively affecting the link between coopetition and sales performance, competitive intensity had a positive moderation effect (Figure 3). While earlier studies have noted that competitive intensity could moderate this relationship in different respects, in highly rivalrous business environments, certain research suggests that such forces may unhinge the coopetition paradox, leading to decision-makers collaborating with rivals that are less trustworthy and yield coopetition-based tensions (following Tidstrom, 2009; Bouncken et al., 2018; reference withheld). However, since there was a positive interaction effect (under low-levels and high-levels of competitive intensity), the competitive business environment might stabilise the coopetition paradox. If there are many competitors within a market, businesses might be able to be more selective of which rivals that they collaborate with and engage in more effective forms of coopetition (Felzensztein and Deans, 2013; Granata et al., 2018; Felzensztein et al., 2019). Owner-managers might find that it is more important to collaborate with competitors across "complementary" product-markets, so that they can obtain mutually-beneficial outcomes, including improved sales performance. One illustration that originated from the field interviews involved cooperation with geographically-distant clubs in certain cases, like senior instructors providing seminars (knowledge sharing), since students/members would not move to those other clubs as they were too far away. In contrast, another 
example from the field interviews established it was usual to borrow equipment from local clubs on a goodwill basis.

\section{[Insert Figure 3 about here]}

This somewhat counter-intuitive result partially addresses a debate pertaining to how the competitive business environment can affect the performance outcomes of coopetition strategies in different ways. This is because proximity may feature as an important factor, such as earlier research in regional clusters where firms are geographically-close to one another. For instance, the nature of competitive intensity is sometimes influenced by a degree of mutual good-will, since each partner benefits as long as all rivals reciprocate, such as via sharing equipment, etc. (Felzensztein and Deans, 2013; Felzensztein et al., 2019; Crick et al., 2020). Additionally, this finding builds upon the importance of the competitive business environment being an integral aspect of resource-based theory and the relational view (Barney, 2001; Priem and Butler, 2001; Lavie, 2006; Dyer et al., 2018). That is, it highlights the need for strategic flexibility in decision-making. In this current study, owner-managers of sporting clubs must be careful when and with whom to collaborate. Indeed, the positive interaction effect reinforces Felzensztein et al.'s (2010) arguments about as more firms are available to network with, they can benefit from having access to the prior-mentioned new resources, capabilities, and opportunities.

Regarding the control paths, firm size had a positive, but non-significant relationship with sales performance. Under resource-based theory, a key assumption is that larger firms, typically with greater resources and capabilities, are likely to obtain higher-levels of performance (like sales) than smaller firms, with fewer resources and capabilities (Barney, 1991). However, this result suggests that firm size is not necessarily an important driver of sales performance. One possible explanation is that smaller-sized businesses have the flexibility and responsiveness to execute certain strategies that larger counterparts cannot achieve (Jones and Rowley, 2011). Moreover, in an overall sense, no clubs were very large, unlike certain companies investigated in earlier entrepreneurial research. A positive and significant relationship existed between firm 
age and sales performance, supporting extensions to resource-based theory and the relational view, namely, older businesses can use their market experience and heritage to out-perform younger competitors (Westhead et al., 2001; Jaskiewicz et al., 2015). Indeed, the field interviews suggested that senior instructors operated some of the more established clubs (or those that had trained under senior instructors), so a degree of social capital existed. As another discussion point, by using these two theoretical perspectives (resourcebased theory and the relational view), this current study explored the cooperative and competitive facets of coopetition activities (Lavie, 2006; Dyer et al., 2018; Crick, 2019). Lastly, this investigation has extended the sports entrepreneurship literature by evaluating the circumstances where coopetition is (and is not) a performance-enhancing entrepreneurial strategy (building upon Robert et al., 2009; Wemmer et al., 2016; Hammerschmidt et al., 2020). This includes exploring coopetition as a set of innovative, proactive, and risktaking behaviours in a sporting arena (linking with Ratten, 2012). Several conclusions follow in the next section.

\section{Conclusions}

\section{Summary}

Under resource-based theory and the relational view, the objective of this study was to explore certain firm level and environmental-level competitive forces affecting the relationship between coopetition and sales performance. The first conclusion is that coopetition has a positive relationship with sales performance. The second conclusion is that inter-firm conflict negatively moderates the coopetition - sales performance relationship. The third conclusion is that somewhat contrary to expectations, competitive intensity positively moderates the relationship between coopetition and sales performance. However, geographic proximity may feature as important in this relationship. The fourth conclusion is that by integrating resource-based theory with the relational view, academics can better-understand the competitive and cooperative aspects of the coopetition construct. The fifth conclusion is that the sampled non-mainstream sporting clubs generated unique "contextual" insights into the implementation of coopetition strategies. 


\section{Practitioner implications}

In addition to its theoretical contributions, this study offers a range of important implications for underresourced practitioners, especially those involved in sports entrepreneurship. First, if entrepreneurs collaborate with their competitors, they can use such strategies to acquire new resources, capabilities, and opportunities that would not be available to them if they were to compete under an individualistic business model. Second, decision-makers should be careful when collaborating with their rivals and build trust, since if they work with untrustworthy competitors, there can be negative effects on their sales performance. It would be most advantageous to collaborate with trustworthy competitors, or at the very least, be able to leave such partnerships if they experience certain tensions (like conflict, power imbalances, and opportunistic behaviours). Third, a factor that could enhance the performance outcomes of coopetition is the degree of competitiveness within a market. As such, if there are many rivals within a market, decision-makers should work with those (via sharing resources and capabilities) that are most likely to yield mutually beneficial outcomes, including improving sales performance. In highly-competitive sectors, there might be opportunities to avoid cooperating with untrustworthy rivals and those that could create coopetition-based tensions. This includes the opportunity to share tangible and intangible assets with competitors targeting "complementary" product-markets. Fourth, from a societal-level and policy angle, sporting governing bodies may wish to encourage more coopetition within their organisations, since it can help their members (potentially being private enterprises) to improve their sales performance. Indeed, they may go further and actively help facilitate network relationships based on knowledge of respective firms' activities; hence, broker complementary and mutually-beneficial partnerships.

\section{Limitations and avenues for future research}

Although this study has contributed to the extant literature, there are certain limitations that can be addressed in future research. First, this study primarily utilised survey data from a sample of small (non-mainstream) sports clubs in a single-country (namely, Taekwon-Do clubs in New Zealand). Although this empirical context 
was highly-suitable for exploring the coopetition construct, it was a rather specific setting. Therefore, in future research, it would be interesting to sample a range of empirical contexts to make inferences into other populations of interest. This could include replicating this study to compare the differences between mainstream and non-mainstream sports. Second, since the substantive data were from a single-source survey (following the initial field interviews for measurement development purposes), future research should attempt to access multi-source data. This could be via accessing archival sources to measure sales performance, although that may be difficult for confidentiality reasons. Equally, in-depth qualitative data could explain "how" and "why" the statistical results existed assuming researchers can facilitate access and especially if longitudinal data is collected, potentially via a case study based approach. Third, despite the sample size accounting for a respectable response rate $(57.63 \%)$, it was still relatively small $(n=151)$. Future research should collect larger volumes of data to yield generalisable results. In closing, these limitations do not pose serious concerns, but instead, present a selection of interesting directions for future research - not least in the sports entrepreneurship context. 


\section{References}

Adams, D. (2018), "The economy of alternative sports", retrieved from: https://economia.icaew.com/features/july-2018/the-economy-of-alternative-sports (accessed 7 July 2019).

Adomako, S., Narteh, B., Danquah, J. and Analoui, F. (2016), "Entrepreneurial orientation in dynamic environments", International Journal of Entrepreneurial Behavior \& Research, Vol. 22 No. 5, pp. 616642.

Ahn, J.D., Hong, S.H. and Park, Y.K. (2009), "The historical and cultural identity of Taekwondo as a traditional Korean martial art", The International Journal of the History of Sport, Vol. 26 No. 11, pp. 1716-1734.

Barney, J.B. (1991), "Firm resources and sustained competitive advantage", Journal of Management, Vol. 17 No. 1 , pp. 99-120.

Barney, J.B. (2001), "Is the resource-based view a useful perspective for strategic management research? Yes", Academy of Management Review, Vol. 26 No. 1, pp. 41-56.

Barney, J.B. (2018), "Why resource-based theory's model of profit appropriation must incorporate a stakeholder perspective", Strategic Management Journal, Vol. 39 No. 13, pp. 3305-3325.

Barney, J.B., Wright, M. and Ketchen Jr., D.J. (2001), "The resource-based view of the firm: ten years after 1991”, Journal of Management, Vol. 27 No. 6, pp. 625-641.

Bengtsson, M. and Johansson, M. (2014), "Managing coopetition to create opportunities for small firms", International Small Business Journal, Vol. 32 No. 4, pp. 401-427.

Bengtsson, M. and Kock, S. (2000), "Coopetition in business networks: to cooperate and compete simultaneously", Industrial Marketing Management, Vol. 29 No. 5, pp. 411-426.

Bengtsson, M. and Kock, S. (2014), "Coopetition - quo vadis? Past accomplishments and future challenges", Industrial Marketing Management, Vol. 43 No. 2, pp. 180-188.

Bernal, S.M.H., Burr, C. and Johnsen, R.E. (2002), "Competitor networks: international competitiveness through collaboration", International Journal of Entrepreneurial Behavior \& Research, Vol. 8 No. 5, pp. 239-253.

Birley, S. and Westhead, P. (1994), "A taxonomy of business start-up reasons and their impact on firm growth and size", Journal of Business Venturing, Vol. 9 No. 1, pp. 7-31.

Boso, N., Story, V.M. and Cadogan, J.W. (2013), "Entrepreneurial orientation, market orientation, network ties, and performance: study of entrepreneurial firms in a developing economy", Journal of Business Venturing, Vol. 28 No. 6, pp. 708-727.

Bouncken, R.B. and Kraus, S. (2013), "Innovation in knowledge-intensive industries: the double-edged sword of coopetition", Journal of Business Research, Vol. 66 No. 10, pp. 2060-2070.

Bouncken, R.B., Fredrich, V., Ritala, P. and Kraus, S. (2018), "Coopetition in new product development alliances: advantages and tensions for incremental and radical innovation", British Journal of Management, Vol. 29 No. 3, pp. 391-410.

Chandler, G.N. and Lyon, D.W. (2001), "Issues of research design and construct measurement in entrepreneurship research: the past decade", Entrepreneurship Theory and Practice, Vol. 25 No. 4, pp. $101-113$. 
Chaudhry, S. and Crick, D. (2004), "The business practices of small Chinese restaurants in the U.K: an exploratory investigation", Journal of Strategic Change, Vol. 13 No. 1, pp. 37-49.

Covin, J.G., Green, K.M. and Slevin, D.P. (2006), "Strategic process effects on the entrepreneurial orientation-sales growth rate relationship", Entrepreneurship Theory and Practice, Vol. 30 No. 1, pp. $57-81$.

Crick, D. and Crick, J.M. (2016a), "Coopetition at the sports marketing/entrepreneurship interface: a case study of a Taekwondo organisation", Marketing Intelligence \& Planning, Vol. 34 No. 2, pp. 169-187.

Crick, J.M. (2019), "Moderators affecting the relationship between coopetition and company performance", Journal of Business \& Industrial Marketing, Vol. 34 No. 2, pp. 518-531.

Crick, J.M. and Crick, D. (2016b), "Developing entrepreneurial resilience in the UK tourism sector", Strategic Change, Vol. 25 No. 3, pp. 315-325.

Crick, J.M. and Crick, D. (2019), "Developing and validating a multi-dimensional measure of coopetition", Journal of Business \& Industrial Marketing, Vol. 34 No. 4, pp. 665-689.

Crick, J.M. and Crick, D. (2020), "Coopetition and COVID-19: collaborative business-to-business marketing strategies in a pandemic crisis", Industrial Marketing Management, Vol. 88 No. 1, pp. 206-213.

Crick, J.M. and Crick, D. (2021), "The Yin and Yang nature of coopetition activities: non-linear effects and the moderating role of competitive intensity for internationalised firms", International Marketing Review (forthcoming).

Crick, J.M., Crick, D. and Peixinho, J.M. (2020), "Does industry experience positively moderate the quadratic relationship between coopetition and financial performance? Evidence from the New Zealand wine sector", International Journal of Entrepreneurship \& Small Business (forthcoming).

Czakon, W., Srivastava, M.K., Le Roy, F. and Gnyawali, D.R. (2020), "Coopetition strategies: critical issues and research directions", Long Range Planning (forthcoming).

Dai, L., Maksimov, V., Gilbert, B.A. and Fernhaber, S.A. (2014), "Entrepreneurial orientation and international scope: the differential roles of innovativeness, proactiveness, and risk-taking", Journal of Business Venturing, Vol. 29 No. 4, pp. 511-524.

Dana, L-P. and Dana, T.E. (2005), "Expanding the scope of methodologies used in entrepreneurship research", International Journal of Entrepreneurship \& Small Business, Vol. 2 No. 1, pp. 79-88.

Dana, L-P., Granata, J., Lasch, F. and Carnaby, A. (2013), "The evolution of co-opetition in the Waipara wine cluster of New Zealand”, Wine Economics and Policy, Vol. 2 No. 1, pp. 42-49.

Dana, L-P. and Winstone, K.E. (2008), "Wine cluster formation in New Zealand: operation, evolution and impact", International Journal of Food Science and Technology, Vol. 43 No. 12, pp. 2177-2190.

Downward, P. and Rasciute, S. (2010), "The relative demands for sports and leisure in England", European Sport Management Quarterly, Vol. 10 No. 2, pp. 189-214.

Dyer, J.H. and Singh, H. (1998), "The relational view: cooperative strategy and sources of inter-organizational competitive advantage”, Academy of Management Review, Vol. 23 No. 4, pp. 660-679.

Dyer, J.H., Singh, H. and Hesterly, W.S. (2018), "The relational view revisited: a dynamic perspective on value creation and value capture", Strategic Management Journal, Vol. 39 No. 12, pp. 3140-3162.

Estrada, I. and Dong, J.Q. (2020), "Learning from experience? Technological investments and the impact of coopetition experience on firm profitability", Long Range Planning (forthcoming). 
Felzensztein, C. and Deans, K.R. (2013), "Marketing practices in wine clusters: insights from Chile", Journal of Business \& Industrial Marketing, Vol. 28 No. 4, pp. 357-367.

Felzensztein, C., Deans, K.R. and Dana, L-P. (2019), "Small firms in regional clusters: local networks and internationalization in the Southern Hemisphere", Journal of Small Business Management, Vol. 57 No. 2, pp. 496-516.

Felzensztein, C., Gimmon, E. and Carter, S. (2010), "Geographical co-location, social networks and interfirm marketing co-operation: the case of the salmon industry", Long Range Planning, Vol. 43 Nos. 5/6, pp. 675-690.

Felzensztein, C., Gimmon, E. and Deans, K.R. (2018), "Coopetition in regional clusters: keep calm and expect unexpected changes", Industrial Marketing Management, Vol. 69 No. 1, pp. 116-124.

Felzensztein, C., Stringer, C., Benson-Rea, M. and Freeman, S. (2014), "International marketing strategies in industrial clusters: insights from the Southern Hemisphere", Journal of Business Research, Vol. 67 No. 5, pp. 837-846.

Granata, J., Lasch, F., Le Roy, F. and Dana, L-P. (2018), "How do micro-firms manage coopetition? A study of the wine sector in France", International Small Business Journal, Vol. 36 No. 3, pp. 331-355.

Hammerschmidt, J., Eggers, F., Kraus, S., Jones, P. and Filser, M. (2020), "Entrepreneurial orientation in sports entrepreneurship-a mixed methods analysis of professional soccer clubs in the German-speaking countries", International Entrepreneurship and Management Journal, Vol. 16 No. 3, pp. 839-857.

Hannah, D.P. and Eisenhardt, K.M. (2018), "How firms navigate cooperation and competition in nascent ecosystems", Strategic Management Journal, Vol. 39 No. 12, pp. 3163-3192.

Hoffmann, W., Lavie, D., Reuer, J.J. and Shipilov, A. (2018), "The interplay of competition and cooperation", Strategic Management Journal, Vol. 39 No. 12, pp. 3033-3052.

Jaskiewicz, P., Combs, J.G. and Rau, S.B. (2015), "Entrepreneurial legacy: toward a theory of how some family firms nurture transgenerational entrepreneurship", Journal of Business Venturing, Vol. 30 No. 1, pp. 29-49.

Jones, R. and Rowley, J. (2011), "Entrepreneurial marketing in small businesses: a conceptual exploration", International Small Business Journal, Vol. 29 No. 1, pp. 25-36.

Katsikeas, C.S., Samiee, S. and Theodosiou, M. (2006), "Strategy fit and performance consequences of international marketing standardization", Strategic Management Journal, Vol. 27 No. 9, pp. 867-890.

Kellermanns, F., Walter, J., Crook, T.R., Kemmerer, B. and Narayanan, V. (2016), "The resource-based view in entrepreneurship: a content-analytical comparison of researchers' and entrepreneurs' views", Journal of Small Business Management, Vol. 54 No. 1, pp. 26-48.

Knight, G.A. (1997), "Cross-cultural reliability and validity of a scale to measure firm entrepreneurial orientation", Journal of Business Venturing, Vol. 12 No. 3, pp. 213-225.

Kraus, S., Klimas, P., Gast, J. and Stephan, T. (2019), "Sleeping with competitors: forms, antecedents and outcomes of coopetition of small and medium-sized craft beer breweries", International Journal of Entrepreneurial Behavior \& Research, Vol. 25 No. 1, pp. 50-66.

Lavie, D. (2006), "The competitive advantage of inter-connected firms: an extension of the resource-based view", Academy of Management Review, Vol. 31 No. 3, pp. 638-658.

Lindell, M.K. and Whitney, D.J. (2001), "Accounting for common method variance in cross-sectional research designs", Journal of Applied Psychology, Vol. 86 No. 1, pp. 114-121. 
Lorgnier, N. and Su, C.J. (2014), "Considering coopetition strategies in sport tourism networks: a look at the non-profit nautical sports clubs on the northern coast of France", European Sport Management Quarterly, Vol. 14 No. 1, pp. 87-109.

Marvel, M.R. and Lumpkin, G.T. (2007), "Technology entrepreneurs' human capital and its effects on innovation radicalness", Entrepreneurship Theory and Practice, Vol. 31 No. 6, pp. 807-828.

McGee, J.E. and Peterson, M. (2019), "The long-term impact of entrepreneurial self-efficacy and entrepreneurial orientation on venture performance", Journal of Small Business Management, Vol. 57 No. 3, pp. 720-737.

Miles, M.B. and Huberman, A.M. (1994), Qualitative Data Analysis: An Expanded Sourcebook, second edition, Sage Publications Limited, Thousand Oaks: CA.

Moenig, U. and Kim, M. (2017), "A critical review of the historical formation of Olympic-style Taekwondo's institutions and the resulting present-day inconsistencies", The International Journal of the History of Sport, Vol. 34 No. 12, pp. 1323-1342.

Morgan, N.A., Vorhies, D.W. and Mason, C.H. (2009), "Market orientation, marketing capabilities, and firm performance", Strategic Management Journal, Vol. 30 No. 8, pp. 909-920.

Morgan, T., Anokhin, S., Kretinin, A. and Frishammar, J. (2015), "The dark-side of the entrepreneurial orientation and market orientation interplay: a new product development perspective", International Small Business Journal, Vol. 33 No. 7, pp. 731-751.

Nason, R.S. and Wiklund, J. (2018), "An assessment of resource-based theorizing on firm growth and suggestions for the future", Journal of Management, Vol. 44 No. 1, pp. 32-60.

Newby, R., Watson, J. and Woodliff, D. (2003), "SME survey methodology: response rates, data quality, and cost effectiveness", Entrepreneurship Theory and Practice, Vol. 28 No. 2, pp. 163-172.

Podsakoff, P.M., MacKenzie, S.B., Lee, J-Y. and Podsakoff, N.P. (2003), "Common method biases in behavioral research: a critical review of the literature and recommended remedies", Journal of Applied Psychology, Vol. 88 No. 5, pp. 879-903.

Poutziouris, P. (2003), "The strategic orientation of owner-managers of small ventures", International Journal of Entrepreneurial Behavior \& Research, Vol. 9 No. 5, pp. 185-214.

Priem, R.L. and Butler, J.E. (2001), "Is the resource-based view a useful perspective for strategic management research?", Academy of Management Review, Vol. 26 No. 1, pp. 22-40.

Ratten, V. (2010), "The future of sports management: a social responsibility, philanthropy and entrepreneurship perspective", Journal of Management \& Organization, Vol. 16 No. 4, pp. 488-494.

Ratten, V. (2012), "Guest editor's introduction: sports entrepreneurship - towards a conceptualisation", International Journal of Entrepreneurial Venturing, Vol. 4 No. 1, pp. 1-17.

Ratten, V. (2016), "The dynamics of sport marketing", Marketing Intelligence \& Planning, Vol. 34 No. 2, pp. 162-168.

Ratten, V. (2019), "Sport entrepreneurship and public policy: future trends and research developments", Journal of Entrepreneurship and Public Policy, Vol. 8 No. 1, pp. 207-216.

Ratten, V. and Ratten, H. (2011), "International sport marketing: practical and future research implications", Journal of Business \& Industrial Marketing, Vol. 26 No. 8, pp. 614-620. 
Raza-Ullah, T., Bengtsson, M. and Kock, S. (2014), "The coopetition paradox and tension in coopetition at multiple-levels", Industrial Marketing Management, Vol. 43 No. 2, pp. 189-198.

Ray, G., Barney, J.B. and Muhanna, W.A. (2004), "Capabilities, business processes, and competitive advantage: choosing the dependent variable in empirical tests of the resource-based view", Strategic Management Journal, Vol. 25 No. 1, pp. 23-37.

Ritala, P. (2012), "Coopetition strategy - when is it successful? Empirical evidence on innovation and market performance", British Journal of Management, Vol. 23 No. 3, pp. 307-324.

Ritala, P. and Hurmelinna-Laukkanen, P. (2013), "Incremental and radical innovation in coopetition: the role of absorptive capacity and appropriability", Journal of Product Innovation Management, Vol. 30 No. 1, pp. 154-169.

Robert, E., Marques, P. and Le Roy, F. (2009), "Coopetition between SMEs: an empirical study of French professional Football", International Journal of Entrepreneurship \& Small Business, Vol. 8 No. 1, pp. 2243.

Semadeni, M., Withers, M.C. and Certo, S.T. (2014), "The perils of endogeneity and instrumental variables in strategy research: understanding through simulations", Strategic Management Journal, Vol. 35 No. 7 , pp. 1070-1079.

Schillo, R.S., Persaud, A. and Jin, M. (2016), "Entrepreneurial readiness in the context of national systems of entrepreneurship", Small Business Economics, Vol. 46 No. 7, pp. 619-637.

Slater, S.F., Olson, E.M. and Hult, G.T.M. (2006), "The moderating influence of strategic orientation on the strategy formation capability-performance relationship", Strategic Management Journal, Vol. 26 No. 12, pp. 1221-1231.

Suddaby, R. (2006), "From the editors: what grounded theory is not", Academy of Management Journal, Vol. 49 No. 4, pp. 633-642.

The Business Research Company. (2018), "Global sports market", retrieved from: https://www.thebusinessresearchcompany.com/report/sports-market (accessed 7 July 2019).

Thomas, L.C., Painbeni, S. and Barton, H. (2013), "Entrepreneurial marketing within the French wine industry", International Journal of Entrepreneurial Behavior \& Research, Vol. 19 No. 2, pp. 238-260.

Tidstrom, A. (2009), "Causes of conflict in inter-competitor cooperation", Journal of Business \& Industrial Marketing, Vol. 24 No. 7, pp. 506-518.

Tiwana, A. (2008), "Does inter-firm modularity complement ignorance? A field study of software outsourcing alliances", Strategic Management Journal, Vol. 29 No. 11, pp. 1241-1252.

Trussell, D.E. (2016), "Young people's perspectives of parent volunteerism in community youth sport", Sport Management Review, Vol. 19 No. 3, 332-342.

Vos, S. and Scheerder, J. (2014), "Fact or fiction? An empirical analysis of cooperation between mass sport providers at the local-level", European Journal for Sport and Society, Vol. 11 No.1, pp. 7-34.

Wemmer, F., Emrich, E. and Koenigstorfer, J. (2016), "The impact of coopetition-based open innovation on performance in non-profit sports clubs", European Sport Management Quarterly, Vol. 16 No. 3, pp. 341363.

Westhead, P., Wright, M. and Ucbasaran, D. (2001), "The internationalization of new and small firms: a resource-based view", Journal of Business Venturing, Vol. 16 No. 4, pp. 333-358. 
Wiklund, J. and Shepherd, D. (2005), "Entrepreneurial orientation and small business performance: a configurational approach", Journal of Business Venturing, Vol. 20 No. 1, pp. 71-91.

World Trademark Review. (2017), "As remarkable growth of sports industry continues, exclusive data analysis reveals the key trademark", retrieved from: https://www.worldtrademarkreview.com/brandmanagement/remarkable-growth-sports-industry-continues-exclusive-data-analysis-reveals (accessed 7 July 2019).

Xie, J., Song, X.M. and Stringfellow, A. (1998), "Inter-functional conflict, conflict resolution styles, and new product success: a four-culture comparison", Management Science, Vol. 44 No. 12, pp. 192-206. 


\section{Figure 1. Conceptual framework}

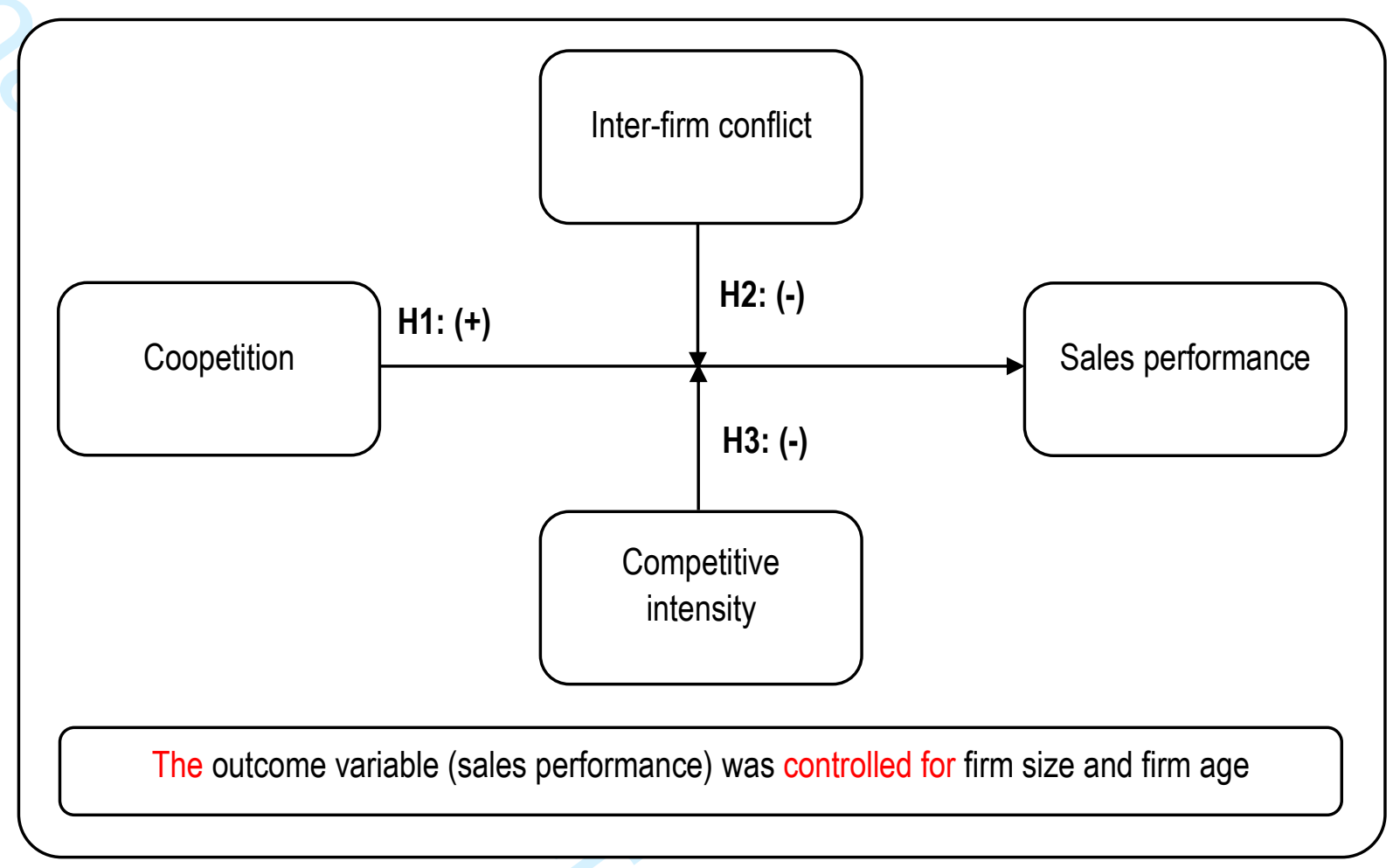


Figure 2. Moderating effects from inter-firm conflict

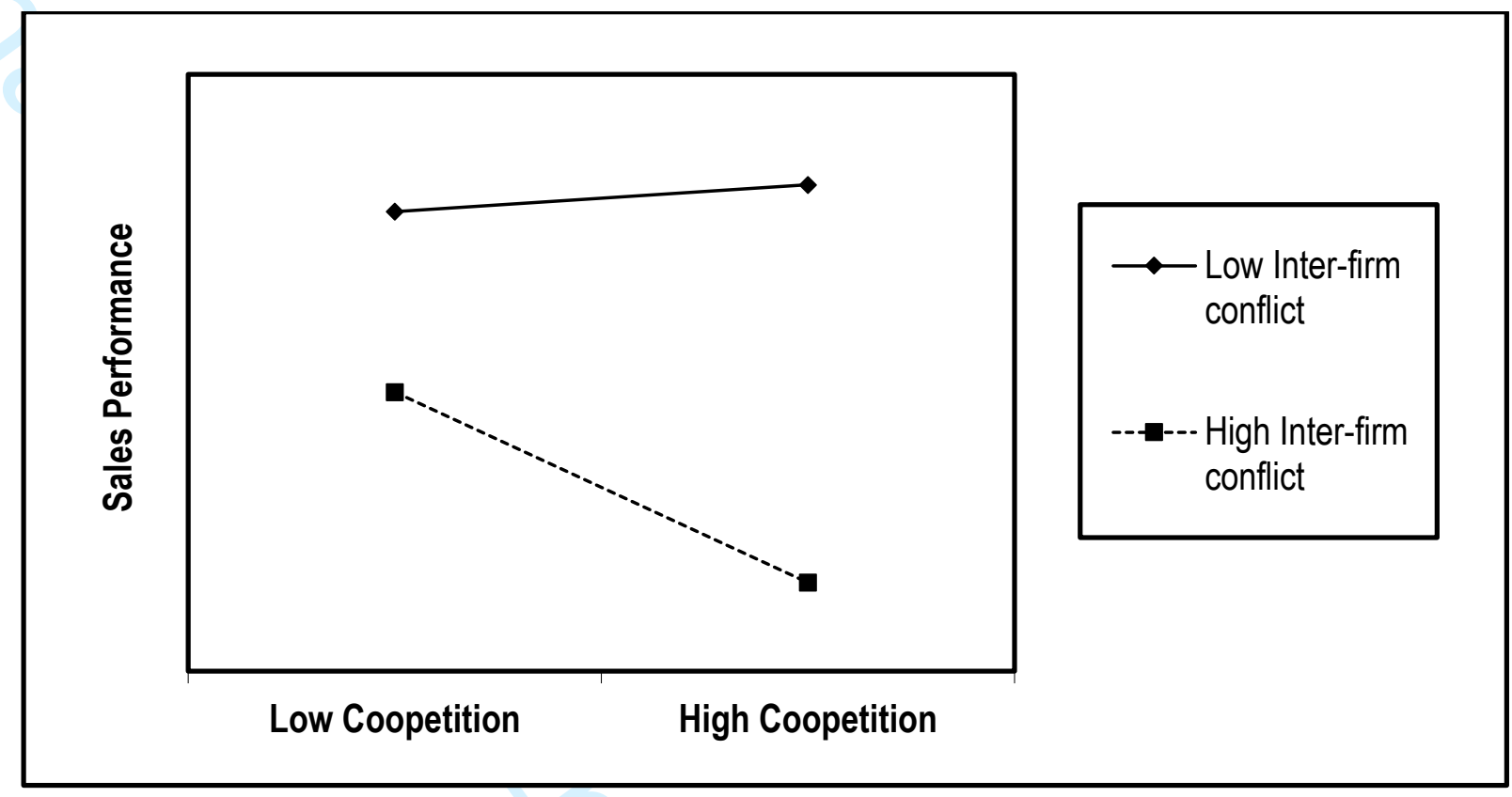

Figure 3. Moderating effects from competitive intensity

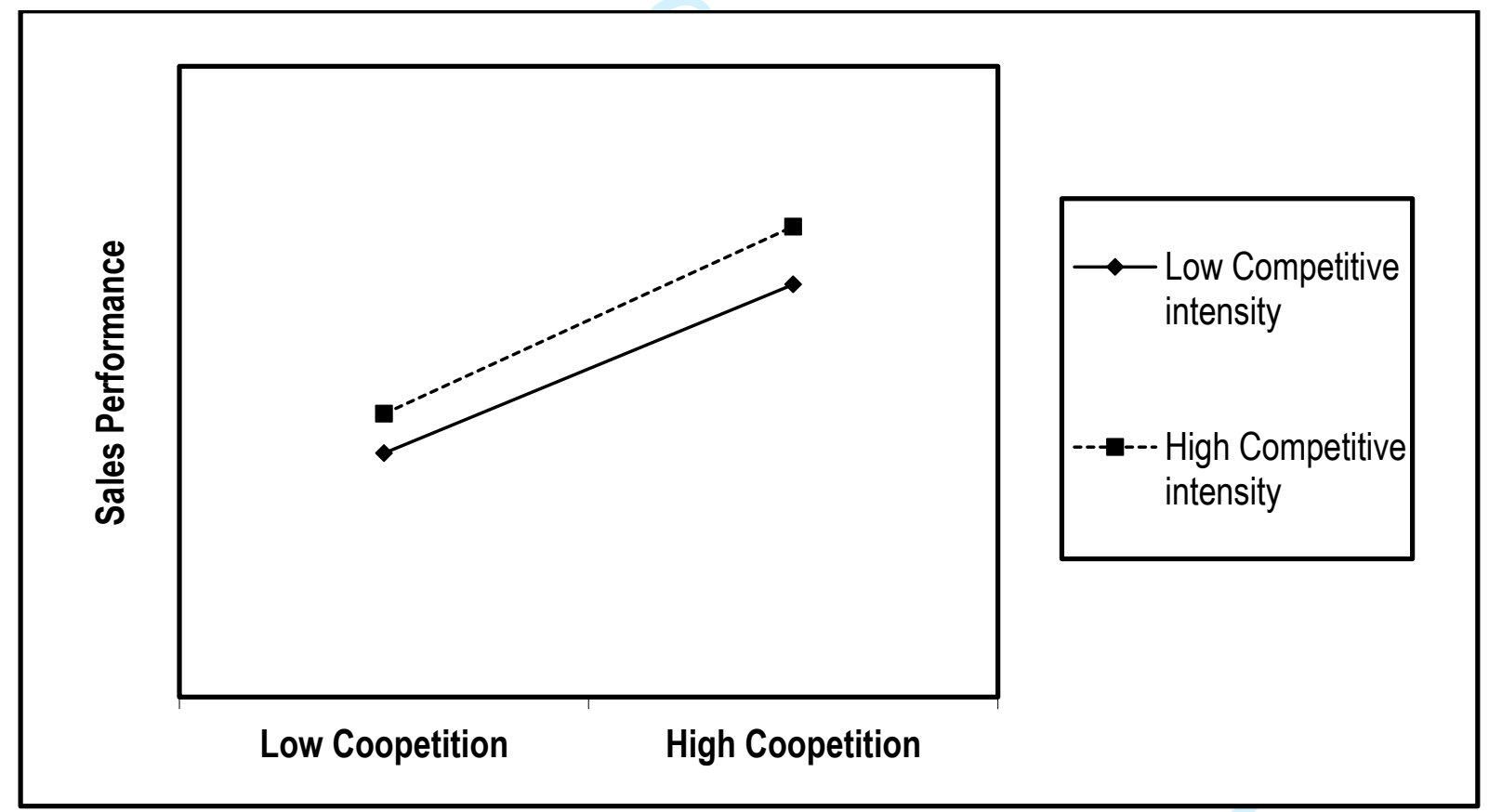


Table 1. Characteristics of the final sample

\begin{tabular}{|l|c|c|c|c|}
\hline Characteristics & Mean & $\begin{array}{c}\text { Standard } \\
\text { deviation }\end{array}$ & Minimum & Maximum \\
\hline Years training in Taekwon-Do & 21.54 & 9.02 & 2.30 & 65.00 \\
\hline Years as a Taekwon-Do instructor & 12.38 & 7.73 & 0.00 & 39.30 \\
\hline Number of Taekwon-Do students & 70.01 & 42.31 & 3.00 & 300.00 \\
\hline Number of Taekwon-Do instructors & 5.27 & 4.86 & 1.00 & 59.00 \\
\hline Age of the Taekwon-Do clubs (years) & 31.67 & 7.63 & 9.00 & 47.00 \\
\hline
\end{tabular}

Table 2. Exploratory factor analysis model

\begin{tabular}{|l|c|c|c|c|c|c|}
\hline & \multicolumn{7}{c|}{ Components } \\
\hline Items & Factor 1 & Factor 2 & Factor 3 & Factor 4 & Factor 5 & Factor 6 \\
\hline COM_1 & $\mathbf{0 . 8 2}$ & 0.04 & -0.27 & 0.05 & -0.24 & 0.01 \\
\hline COM_2 & $\mathbf{0 . 8 5}$ & 0.08 & -0.20 & -0.01 & -0.21 & -0.03 \\
\hline COM_3 & $\mathbf{0 . 8 0}$ & 0.04 & -0.21 & 0.10 & -0.07 & 0.09 \\
\hline COM_4 & $\mathbf{0 . 8 0}$ & -0.03 & -0.20 & 0.00 & 0.11 & 0.04 \\
\hline COM_5 & $\mathbf{0 . 8 1}$ & 0.10 & -0.27 & 0.06 & -0.10 & 0.09 \\
\hline COM_6 & $\mathbf{0 . 7 0}$ & 0.08 & -0.35 & -0.01 & -0.03 & -0.03 \\
\hline COOP_1 & 0.13 & $\mathbf{0 . 8 8}$ & -0.08 & 0.25 & -0.10 & -0.09 \\
\hline COOP_2 & 0.11 & $\mathbf{0 . 9 1}$ & -0.08 & 0.16 & -0.04 & -0.07 \\
\hline COOP_3 & 0.14 & $\mathbf{0 . 9 6}$ & -0.08 & 0.20 & -0.07 & -0.09 \\
\hline CONF_1 & -0.33 & -0.11 & $\mathbf{0 . 8 0}$ & 0.00 & 0.09 & -0.05 \\
\hline CONF_2 & -0.23 & -0.09 & $\mathbf{0 . 8 9}$ & -0.02 & 0.05 & -0.03 \\
\hline CONF_3 & -0.39 & -0.04 & $\mathbf{0 . 6 2}$ & -0.02 & 0.06 & 0.19 \\
\hline CONF_4 & -0.27 & -0.01 & $\mathbf{0 . 9 0}$ & 0.03 & 0.18 & -0.02 \\
\hline CONF_5 & -0.28 & -0.06 & $\mathbf{0 . 8 8}$ & -0.05 & -0.02 & -0.01 \\
\hline SALES_1 & -0.01 & 0.25 & 0.02 & $\mathbf{0 . 8 4}$ & 0.01 & 0.02 \\
\hline SALES_2 & -0.02 & 0.14 & -0.02 & $\mathbf{0 . 9 3}$ & 0.07 & -0.01 \\
\hline SALES_3 & 0.03 & 0.15 & -0.04 & $\mathbf{0 . 9 1}$ & 0.18 & 0.04 \\
\hline COMP_1 & -0.12 & -0.09 & 0.11 & 0.05 & $\mathbf{0 . 8 3}$ & 0.15 \\
\hline COMP_2 & -0.05 & -0.02 & 0.07 & 0.03 & $\mathbf{0 . 8 9}$ & 0.11 \\
\hline COMP_3 & -0.12 & -0.07 & 0.13 & -0.02 & $\mathbf{0 . 8 5}$ & 0.16 \\
\hline INQ_1 & 0.09 & -0.11 & -0.05 & -0.06 & 0.25 & $\mathbf{0 . 8 2}$ \\
\hline INQ_2 & 0.08 & -0.08 & 0.02 & -0.02 & 0.19 & $\mathbf{0 . 9 3}$ \\
\hline INQ_3 & 0.11 & -0.02 & 0.08 & 0.06 & -0.01 & $\mathbf{0 . 8 7}$ \\
\hline INQ_4 & -0.04 & -0.03 & -0.01 & 0.01 & 0.06 & $\mathbf{0 . 9 4}$ \\
\hline INQ_5 & -0.08 & 0.01 & -0.01 & 0.06 & 0.04 & $\mathbf{0 . 9 3}$ \\
\hline The items presented in a bold font represent those used to operationalise each latent variable \\
within the six-factor solution. & & & & & \\
\hline & & & & & & \\
\hline
\end{tabular}


Table 3. Confirmatory factor analysis model

\begin{tabular}{|l|c|c|c|}
\hline Items & $\begin{array}{c}\text { Standardised factor } \\
\text { loadings }(\boldsymbol{\lambda} \mathbf{x})\end{array}$ & $\begin{array}{c}\text { Standardised error } \\
\text { variances }(\boldsymbol{\theta} \boldsymbol{\delta})\end{array}$ & $\boldsymbol{t}$-values \\
\hline COM_1 & 0.99 & 0.03 & 12.73 \\
\hline COM_2 & 0.89 & 0.21 & Fixed \\
\hline COOP_1 & 1.00 & 0.00 & Fixed \\
\hline COOP_2 & 0.76 & 0.42 & 14.67 \\
\hline CONF_1 & 0.81 & 0.34 & 19.11 \\
\hline CONF_2 & 0.90 & 0.20 & Fixed \\
\hline CONF_4 & 0.94 & 0.12 & 23.81 \\
\hline CONF_5 & 0.96 & 0.08 & 13.12 \\
\hline SALES_1 & 0.80 & 0.37 & Fixed \\
\hline SALES_2 & 0.94 & 0.12 & 15.86 \\
\hline SALES_3 & 0.89 & 0.21 & Fixed \\
\hline COMP_1 & 0.79 & 0.37 & 10.79 \\
\hline COMP_2 & 0.88 & 0.23 & 10.34 \\
\hline COMP_3 & 0.81 & 0.34 & Fixed \\
\hline INQ2 & 0.83 & 0.31 & 17.82 \\
\hline INQ_4 & 1.00 & 0.00 & 17.09 \\
\hline INQ_5 & 0.96 & 0.07 & Fixed \\
\hline SIZE & 1.00 & 0.00 & Fixed \\
\hline AGE & 1.00 & 0.00 & \\
\hline The critical $t$-value was $1.65(5 \%, 0 n e-s i d e d)$. & & \\
\hline
\end{tabular}

Table 4. Final multi-item scale reliabilities

\begin{tabular}{|l|c|c|c|c|}
\hline Scales & Alpha $(\boldsymbol{\alpha})$ & Items $(\boldsymbol{n})$ & CR & AVE \\
\hline Coopetition & 0.86 & 2 & 0.88 & 0.79 \\
\hline Inter-firm conflict & 0.94 & 4 & 0.95 & 0.82 \\
\hline Competitive intensity & 0.86 & 3 & 0.87 & 0.69 \\
\hline Company performance & 0.90 & 3 & 0.91 & 0.77 \\
\hline Informant quality (marker variable) & 0.90 & 3 & 0.91 & 0.87 \\
\hline Coopetition-oriented mind-set (instrument) & 0.93 & 2 & 0.94 & 0.88 \\
\hline
\end{tabular}

Table 5. Bivariate correlations and descriptive statistics

\begin{tabular}{|l|c|c|c|c|c|c|}
\hline Latent variables & $\mathbf{1 .}$ & $\mathbf{2 .}$ & $\mathbf{3 .}$ & $\mathbf{4 .}$ & $\mathbf{5 .}$ & $\mathbf{6 .}$ \\
\hline 1. Coopetition & 1.00 & & & & & \\
\hline 2. Inter-firm conflict & $-0.19^{* *}$ & 1.00 & & & & \\
\hline 3. Competitive intensity & $-0.18^{* *}$ & $0.24^{* * *}$ & 1.00 & & & \\
\hline 4. Sales performance & $0.40^{* * *}$ & -0.04 & 0.03 & 1.00 & & \\
\hline 5. Firm size & -0.02 & 0.05 & 0.02 & 0.05 & 1.00 & \\
\hline 6. Firm age & $0.13^{*}$ & 0.09 & -0.01 & $0.29^{* * *}$ & 0.02 & 1.00 \\
\hline Mean & 4.43 & 2.65 & 4.25 & 5.73 & 4.18 & 4.50 \\
\hline Standard deviation & 1.29 & 1.13 & 0.76 & 1.54 & 4.50 & 1.59 \\
\hline Minimum & 1.00 & 1.00 & 1.00 & 1.00 & 1.39 & 1.00 \\
\hline Maximum & 7.00 & 7.00 & 7.00 & 9.00 & 5.74 & 8.00 \\
\hline${ }^{*} \boldsymbol{p}<\mathbf{0 . 1 0 ;}{ }^{* *} \boldsymbol{p}<\mathbf{0 . 0 5 ; ~}{ }^{* * *} \boldsymbol{p}<\mathbf{0 . 0 1}$ (one-tailed tests). \\
\hline
\end{tabular}


Table 6. Hierarchical regression analysis

\begin{tabular}{|c|c|c|c|c|c|c|c|c|c|c|c|c|}
\hline$x^{2}$ & \multicolumn{2}{|c|}{ Step 1} & \multicolumn{2}{|c|}{ Step 2} & \multicolumn{2}{|c|}{ Step 3} & \multicolumn{2}{|c|}{ Step 4} & \multicolumn{2}{|c|}{ Step 5} & \multicolumn{2}{|c|}{ Step 6} \\
\hline Paths & $\beta$ & $t$-values & $\beta$ & $t$-values & $\beta$ & $t$-values & $\beta$ & $t$-values & $\beta$ & $t$-values & $\beta$ & $t$-values \\
\hline SIZE & 0.12 & 0.58 & 0.13 & 0.73 & 0.13 & 0.72 & 0.13 & 0.71 & 0.14 & 0.77 & 0.14 & 0.78 \\
\hline AGE & 0.27 & $3.61^{* * *}$ & 0.23 & $3.21^{* * *}$ & 0.23 & $3.17^{* * *}$ & 0.23 & $3.19^{* * *}$ & 0.23 & $3.25^{* * *}$ & 0.23 & $3.28^{* * *}$ \\
\hline COOP & & & 0.44 & $4.97^{* * *}$ & 0.44 & $4.87^{* * *}$ & 0.46 & $5.01^{* * *}$ & 0.51 & $5.38^{* * *}$ & 0.48 & $5.20^{* * *}$ \\
\hline CONF & & 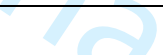 & 4 & & 0.01 & 0.13 & -0.02 & -0.15 & 0.27 & 1.47 & 0.33 & $1.78^{*}$ \\
\hline COMP & & +3 & & & & & 0.20 & 1.29 & 0.18 & 1.14 & -0.27 & -1.10 \\
\hline COOPxCONF & & & 1 & 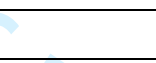 & & & & & -0.07 & $-1.87^{*}$ & -0.08 & $-2.14^{* *}$ \\
\hline COOPxCOMP & & & 8 & 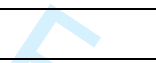 & & & & & & & 0.11 & $2.30^{\star *}$ \\
\hline & & & & 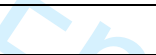 & & & & & & & & \\
\hline Model fit & & & & 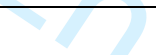 & & & & & & & & \\
\hline$R^{2}$ & 0.08 & & 0.21 & & 0.22 & & 0.22 & & 0.24 & & 0.27 & \\
\hline Adjusted $R^{2}$ & 0.07 & & 0.19 & & 0.19 & & 0.20 & & 0.21 & & 0.23 & \\
\hline & & & & & $\theta$ & & & & & & & \\
\hline Changes & & & & & & 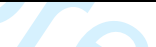 & & & & & & \\
\hline$\Delta R^{2}$ & 0.08 & & 0.13 & & 0.01 & +2 & 0.00 & & 0.02 & & 0.03 & \\
\hline$\Delta F$ & $6.70^{* * *}$ & & $24.66^{\star \star *}$ & & 0.02 & 4 & 1.67 & & $3.51^{*}$ & & $5.28^{* *}$ & \\
\hline
\end{tabular}




\section{Appendix 1. Full-list of the multi-item scales}

\section{Coopetition}

In the ITF...

- COOP_1 - ... we collaborate with competing clubs to achieve a common goal

- COOP_2 - ... an active cooperation with our competing clubs is important to members

- COOP_3 - ... we share assets with other Taekwon-Do clubs (like equipment)

Anchors: 1 = very strongly disagree to 7 = very strongly agree (adapted from Bouncken and Kraus, 2013; Bouncken et al., 2018)

\section{Sales performance}

Please evaluate your ITF Taekwon-Do club's performance over the past year, relative to your objectives, as an instructor:

- SALES_1 - acquiring new students

- SALES_2 - volume of students

- SALES_3 - revenue volume growth from students

Anchors: 1 = extremely dissatisfied to 9 = extremely satisfied (adapted from Morgan et al., 2009)

\section{Competitive intensity}

In our ITF Taekwon-Do club's current environment...

- COMP_1 - ... competition for student membership is cut-throat

- COMP_2 - ... anything that one club can offer, others can match readily

- COMP_3 - ... our rival clubs are relatively strong

Anchors: 1 = very strongly disagree to 7 = very strongly agree (adapted from Slater et al., 2006)

\section{Inter-firm conflict}

In the ITF...

- CONF_1 - ... when members of several clubs get together, tensions frequently run high

- CONF_2 - ... members in one club dislike interacting with members from other clubs

- CONF_3 - ... protecting one's club is generally considered to be a way of life

- CONF_4 - ... there is a lot of conflict between members of different clubs

- CONF_5 - ... most members across different clubs do not get along with one another

Anchors: 1 = very strongly disagree to 7 = very strongly agree (adapted from Xie et al., 1998)

\section{Coopetition-oriented mind-set}

In the ITF...

- COM_1 - ... members are cooperative across competing clubs

- COM_2 - ... members believe in assisting other clubs

- COM_3 - ... all rival clubs should cooperate with one another

- COM_4 - ... clubs should share assets (e.g., equipment) with rivals as much as possible

- COM_5 - ... it is important for members to be collaborative with rival clubs

- COM_6 - ... we have a culture that focuses on cooperating with competing clubs 
Anchors: 1 = very strongly disagree to 7 = very strongly agree (adapted from Crick and Crick, 2019)

Informant quality

In closing to the survey:

- INQ_1 - I am confident about my answers to the questions

- INQ_2 - I am confident that my answers reflect our club's situation

- INQ_3 - This survey deals with issues I am very knowledgeable about

- INQ_4 - My current role qualifies me as an appropriate person to complete this survey

- INQ_5 - I am competent to answer the above questions

Anchors: 1 = very strongly disagree to 7 = very strongly agree (adapted from Boso et al., 2013) 